\title{
PERAN WANITA DALAM PENINGKATAN EKONOMI KELUARGA MELALUI USAHA HOMESTAY BERBASIS RUMAH TINGGAL DI DESA WISATA KAMPOENG BOENGA GRANGSIL
}

\author{
Tonny Suhartono $^{1}$, Diyah Sukanti Cahyaningsih ${ }^{2}$, dan Sri Widayati ${ }^{3}$ \\ ${ }^{1}$ Program Studi Arstektur, Universitas Merdeka Malang \\ ${ }^{2}$ Program Studi Akuntansi, Universitas Merdeka Malang \\ Email: diyahsukanti@unmer.ac.id \\ ${ }^{3}$ Program Studi Ilmu Komunikasi, Universitas Merdeka Malang
}

\begin{abstract}
Tourist destinations should have adequate facilities, such as easy access, destination attractions, and accommodation. Homestay businesses have a very promising potential in improving the economy of the Tourism Village. The condition in Kampoeng Boenga Grangsil, Jambangan Village, Dampit District, Malang Regency still needs improvement. Kampoeng Boenga Grangsil still provides flower shopping destinations, educational flower tourism, and attractive photo spots, but does not have a homestay concept. The team of community service offers assistance in opening a home-based homestay business. This service started with potential data collection and socialization about the homestay business. The community was expected to understand the function and concept of a tourist village homestay. The service team involves the role of PKK members. The role of women especially housewives is very dominant in realizing the concept of a homestay that joins household activities to create the atmosphere of village life that tourists expect. In this concept, the family's daily life will become a commodity. Homestay-based households are intended to provide a unique experience with guest involvement in daily activities. Village atmosphere, clean environment, and the life of flower farmers hopefully will attract prospective lodgers. In addition to focusing on homestay management efforts, the community is also accompanied by procedures for receiving guests and guiding, as well as managing homestay finances. The results of this dedication are expected to be able to provide a discourse for new creative endeavors for PKK members in Grangsil Hamlet, thereby empowering the role of women in supporting the family economy.
\end{abstract}

Keywords: Homestay, improving the domestic economy; tourist village

\begin{abstract}
ABSTRAK
Destinasi wisata hendaknya memiliki sarana yang memadahi, yaitu kemudahan akses, daya tarik destinasi, dan akomodasi. Usaha Homestay di kawasan wisata memiliki potensi yang sangat menjanjikan dalam meningkatkan ekonomi masyarakat Desa Wisata. Kondisi di kampoeng Boenga Grangsil Desa Jambangan Kecamatan Dampit Kabupaten Malang, yang sedang berkembang menjadi destinasi wisata baru, masih perlu peningkatan. Sebelum kegiatan pengabdian ini, Kampoeng Boenga Grangsil masih menyediakan destinasi belanja bunga, edukasi wisata bunga, dan spot foto yang menarik, namun belum memiliki konsep homestay. Dalam rangka pengabdian masyarakat, tim menawarkan bentuk pendampingan pembukaan usaha homestay berbasis rumah tinggal. Pengabdian ini dilaksanakan dengan diawali pendataan potensi dan sosialisasi tentang usaha homestay. Upaya awal ini dilakukan agar masyarakat memahami fungsi dan konsep homestay desa wisata. Dalam mewujudkan usaha berbasis rumah tangga ini tim pengabdi melibatkan peran ibu-ibu anggota PKK. Peran wanita khususnya ibu rumah tangga sangat dominan dalam mewujudkan konsep homestay yang bergabung dengan kegiatan rumah tangga, untuk mewujudkan suasana kehidupan desa yang diharapkan wisatawan. Pada konsep homestay berbasis rumah tinggal ini, keseharian keluarga akan menjadi komoditas. Homestay berbasis rumah tangga ditujukan untuk menghadirkan pengalaman tersediri dengan keterlibatan tamu pada kegiatan sehari-hari. Diharapkan suasana desa yang sejuk, lingkungan yang bersih, dan kehidupan petani bunga menjadi daya tarik calon penginap di homestay ini. Selain fokus pada usaha pengelolaan homestay, masyarakat didampingi pula tata cara penerimaan tamu dan guiding, serta pengelolaan keuangan homestay. Hasil dari pengabdian ini diharapkan mampu memberikan wacana usaha kreatif baru pada ibuibu anggota PKK di Dusun Grangsil, sehingga memberdayakan peran wanita dalam menyokong ekonomi keluarga. Kata Kunci: Desa Wisata; Homestay; peningkatan ekonomi keluarga
\end{abstract}

\section{PENDAHULUAN}

Grangsil adalah sebuah dusun di Desa Jambangan Kecamatan Dampit Kabupaten Malang. Terletak kurang lebih $20 \mathrm{~km}$. arah selatan dari pusat Kota Malang. Dusun ini memiliki potensi pertanian bunga. Pada tahun 2019, Plt. Bupati Malang telah menetapkan Dusun Grangsil sebagi 
Desa Wisata. Desa Wisata adalah kelompok masyarakat dalam interaksi sosial dan budaya pada wilayah yang terbatas, yang mampu mengeksplor peran dan ketrampilan masing-masing untuk menjadi potensi kepariwisataan di daerahnya (Hadiwijono, 2012). Sumberdaya alam yang telah ada di Dusun Grangsil memberikan peluang perkembangan dusun ini untuk menjadi destinasi wisata dan telah terbentuk kelompok masyarakat pengelola wisata yaitu KBG. (Wikantiyoso et al., 2019). Wisata berbasis agro yaitu yang mengusung potensi keanekaragaman kekayaan alam (Astuti, 2014) dapat dikembangkan untuk menambah khasanah destinasi wisata Malang Raya. Kegiatan masyarakat sebagai petani bunga, menjadi unsur utama dalam komunitas desa wisata Kampoeng Boenga Grangsil. Sejauh ini yang telah ada adalah spot foto, taman bunga, green house penjualan bunga dan eduwisata tanam bunga.

Namun sebagaimana dinyatakan oleh Hadiwijono (2012) desa wisata hendaknya memiliki daya dukung berupa 1) Akses transportasi yang memadahi, 2) Obyek wisata potensial (alam, kuliner, budaya). 3) Dukungan Masyarakat. 4) Keamanan 5) akomodasi, telekomunikasi, dan tenaga kerja yang memadai 6) Iklim yang mendukung 7) Akses yang saling terhubung dengan destinasi wisata lain. Maka, di Kampoeng Boenga Grangsil yang belum tersedia adalah sarana akomodasi. Sementara itu kondisi rumah tangga warga, sebagian besar, sangat memungkinkan untuk menerima tamu wisatawan yang menginap. Berdasarkan kondisi tersebut, tim pengabdi Universitas Merdeka Malang memberikan pendampingan pada khususnya ibu rumah tangga anggota PKK yang di Dusun Grangsil ini diberi nama PKK Bunga Matahari, selaku pemeran utama di rumah, yang akan dijadikan homestay dengan konsep bergabung dengan kegiatan sehari-hari warga desa. Ibu-ibu PKK merupakan sasaran binaan yang dirasa tepat, mengingat dalam 10 Program pokok PKK (Tim Penggerak PKK Pusat, 2015) antara lain memuat tentang perumahan dan tatalaksana rumah tangga; pendidikan dan keterampilan; serta kelestarian lingkungan hidup; dan perencanaan sehat. Empat hal tersebuat dapat saling terkait dengan program homestay pada pengabdian ini. Sementara konsep homestay pada desa wisata yang bergabung dengan rumah tinggal ini, ngacu pada konsep Pondok Wisata sesuai KLBI (klasifikasi buku Lapangan Usaha Indonesia) No. 55130 yang mendefinisikan sebagai penginapan umum yang digunakan oleh pemiliknya dan ada interaksi antara pemilik dan penyewa (Kementrian Pariwisata Republik Indonesia, 2018). Homestay jenis ini juga memiliki konsep yang sama dengan homestay wisata Pinge Kabupaten Tabanan yang mengusung tema interaksi kegiatan sehari-hari antara tamu dan pemilik homestay (Prajnawrdhi, 2016). Hal ini memiliki sisi positif pengalaman tentang kearifan budaya lokal bagi pengunjung.

\section{Potensi Sarana Akomodasi dan Peran Ibu Rumah Tangga dalam Mendukung Desa Wisata}

Terdapat beberapa kategori dalam paket wisata Chusmeru (2018) yaitu: just stop for a moment (berhenti sejenak) jenis wisata ini biasanya untuk atraksi budaya, spot swa foto, bersifat tidak variative dan terbatas. Rest for a while jenis wisata ini yang sekarang telah ada di Kampoeng Bunga Grangsil. Pengunjung datang, ber-swa foto, berbelanja bunga, dan ada pilihan eduwisata tanam bunga. Paket wisata yang belum ada adalah enjoy an overnight stay (tinggal inap) paket ini memungkinkan wisatawan untuk menikmati tinggal dan berinteraksi dengan kegiatan sehari-hari penduduk desa. Dalam rangka menarik minat wisatawan untuk menginap, sarana akomodasi yang memadai sangat diperlukan. Pada lingkungan yang beriklim sejuk seperti di Kampoeng Boenga Grangsil, potensi agrowisata akan berkembang dengan baik jika didukung sarana yang memadai (Tyas \& Damayanti, 2018). Pada konsep desa wisata yang dikemukakan oleh Antara \& Arida (2015) sarana akomodasi yang menarik adalah yang dapat memberikan pengalaman baru pada wisatawan. Kondisi ini bukan seperti pembanguna hotel, motel atau homestay yang bersifat tempat usaha. Homestay yang memiliki akses langsung pada kehidupan warga desa jauh lebih menarik. Wisatawan akan merasakan menyatu dengan lingkungan, menikmati keseharian selayaknya warga Kampoeng Boenga Grangsil. 
Ibu Rumah tangga sebagai pelaku utama dalam konsep dan penataan rumah tinggal, menjadi penentu terwujudnya akomodasi homestay berbasis rumah tinggal pada Kampoeng Boenga Grangsil. Ibu rumah tangga berperan dalam semua aspek kegiatan utama dalam sebuah rumah. Aktifitas orang tua, anak-anak, dan pemanfaatan ruang sangat menjadi konsentrasi seorang ibu rumah tangga. Homestay berbasis rumah tinggal, tentunya tidak terpisah dari kegiatan keluarga, maka perlu dipertimbangkan kenyamanan baik bagi pemilik rumah maupun wisatawan.

Dari sisi ekonomi, keberadaan homestay mampu memberikan peningkatan pendapatan rumah tangga. Pemanfaatan ruang yang baik, memungkinkan rumah warga diminati oleh wisatawan. Di sisi lain, ketrampilan ibu rumah tangga dapat menjadi komoditas pendukung, misalnya makanan, kopi, atau kudapan tradisional khas dusun setempat. Dengan pendampingan, diharapkan warga dapat meningkatkan nilai keekonomian rumah mereka, memanfaatkan ruang yang kurang dimanfaatkan menjadi sumber pendapatan baru.

\section{METODE PELAKSANAAN PKM}

Kegiatan pengabdian kepada masyarakat ini melibatkan tim yang terdiri dari 3 disiplin ilmu yang saling bersinergi dalam tujuan membantu masyarakat desa dalam mewujudkan Desa Wisata yang memadahi. Tim membagi tanggungjawab sesuai dengan 3 sasaran utama. Pertama anggota tim yang berlatar belakang ilmu arsitektur bertanggungjawab terhadap kegiatan pendampingan penataan ruang homestay. Kedua, anggota tim dengan latar belakang ilmu komunikasi bertanggungjawab memberikan wawasan dan pendampingan guiding. Ketiga, anggota tim yang berlatar belakang ekonomi akuntansi berrtanggungjawab memberikan pendampingan pencatatan keuangan usaha homestay dan pemasarannya. Interaksi pada masyarakat dijembatani organisai yang ada yaitu Pokdarwis dan Kelompok PKK Bunga Matahari.

Tahap pendampingan yang diterapkan oleh tim pengabdi adalah, pertama sosialisasi tentang usaha homestay:
1. Pendataan Potensi
2. Sosialisasi
3. Penataan dan perbaikan kondisi homestay
4. Pelatihan Guiding
5. Pelatihan Pemasaran dan Pengelolaan Keuangan

\section{HASIL DAN PEMBAHASAN}

Kegiatan pengabdian kepada masyarakat ini dilakukan dalam tahap-tahap berikut:

\section{a. Pendataan Potensi Desa dalam mewujudkan sarana Homestay berbasis Rumah tinggal}

Tim pengabdi melakukan survey untuk mendata warga desa yang bersedia menjadikan rumah tinggalnya sebagai sarana homestay. Rumah tinggal yang ada di Kampoeng Boenga Grangsil cukup potensial. Sebagian besar warga memiliki lahan perumahan yang cukup luas. Jumlah kamar dalam rumah-rumah tersebut memungkinkan untuk menampung tamu. Sanitasi yang cukup baik, dan terutama karakteristik warga yang sangat hangat dan bersahabat. Dari sudut pandang prasarana, mengadakan homestay berbasis rumah tinggal sangat memungkinkan. Tabel 1 merangkum hasil survey potensi rumah warga yang memungkinkan untuk membuka homestay. 
Tabel 1. Jumlah Rumah yang Potensial

\begin{tabular}{lccc}
\hline & Ukuran kecil & Ukuran Sedang & Ukuran Besar \\
\hline Jumlah & 6 & 9 & 5 \\
\hline Kapasitas & 2 tamu & 5 tamu & 10 tamu \\
\hline $\begin{array}{l}\text { Jumlah Kamar tidur yang } \\
\text { bisa dimanfaatkan untuk } \\
\text { tamu }\end{array}$ & 1 & 2 & 3 \\
\hline Sarana MCK & 1 & 2 & 2 \\
\hline Sarana air bersih & Sumur & Sumur & Sumur \\
\hline Ruang Tamu & Bergabung & Bergabung & Terpisah \\
\hline $\begin{array}{l}\text { Jumlanh Anggota keluarga } \\
\text { yang ada }\end{array}$ & $3-5$ & $4-5$ & \begin{tabular}{c} 
Lebih dari 5 \\
\hline Potensi Rumah tangga
\end{tabular} \\
$\begin{array}{l}\text { Potensi kekhasan rumah } \\
\text { desa }\end{array}$ & Kuliner & Kuliner & $\begin{array}{c}\text { Kuliner dan Kebun } \\
\text { bibit }\end{array}$ \\
\hline
\end{tabular}

Sumber: Penulis, 2020

Jumlah tersebut untuk sementara dirasa cukup memenuhi kebutuhan calon wisatawan. Namun tidak menutup kemungkinan akan ada tambahan warga yang bersedia membuka homestay pada kesempatan yang akan datang.

\section{b. Sosialisasi tentang homestay sebagai salah satu sarana Desa Wisata pada ibu-ibu anggota PKK}

Antara \& Arida (2015) menyatakan ada 4A Komponen utama Desa Wisata yaitu Attraction (daya tarik), Accessibility (keterjangkauan), Amenity (fasilitas pendukung), dan Ancilliary (organisasi/kelembagaan pendukung). Selain organisasi yang sudah ada yaitu Pokdarwis (Kelompok Sadar Wisata), anggota PKK Bunga Matahari juga dilibatkan, mengingat peran ibu rumah tangga dalam keberadaan homestay berbasis rumah tinggal. Tim pengabdi merasa sangat penting untuk memberikan sosialisasi kepada ibu-ibu anggota PKK Bunga Matahari. Pokok-pokok yang disampaikan dalam sosialisasi ini adalah peluang dan tantangan yang ada dalam pengembangan Desa Wisata. Pada sosialisasi ini warga dengan sangat terbuka dapat mencurahkan ide, dan pertanyaan. Sosialisasi dan kondisi Kampoeng Boenga Grangsil dapat dilihat pada Gambar 1 dan Gambar 2. Keinginan dan kendala yang dapat disimpulkan dari sosialisasi tentang homestay berbasis rumah tinggal dapat dilihat pada Tabel 2.

Tabel 2. Rangkuman Curah Pendapat Bersama Anggota PKK

\begin{tabular}{lll}
\hline \multicolumn{1}{c}{ Keinginan: } & \multicolumn{1}{c}{ Kendala: } \\
\hline - Menambah jumlah kunjungan wisatawan & $\bullet$ Sarana di dalam rumah yang belum memadai \\
- Menambah daya tarik dengan wisata kuliner & $\bullet$ Kekhawatiran keamanan dan kenyamanan \\
- Meningkatkan pendapatan keluarga & $\bullet$ Merasa belum siap menjadi tuan rumah yang baik \\
\hline
\end{tabular}

Sumber: Penulis, 2020

\section{c. Penataan dan perbaikan kondisi homestay}

Dalam menunjang kenyamanan wisatawan sekaligus pemilik rumah, perlu ada penataan layout yang lebih baik pada beberapa rumah. Salah satu contoh pada rumah yang menjadi obyek pengabdian, layout awal belum tertata dengan baik. Perabot cukup banyak namun karena belum ditata dengan baik tampak tidak menarik. Dengan penambahan sekat ruang dan penataan perabot yang lebih rapi. Hal ini dapat menjadi daya tarik wisatawan yang menginap, dan juga menjaga 
privacy kedua belah pihak. Gambar 3 menjelaskan salah satu contoh penataan ruang yang diarahkan oleh tim pengabdi.

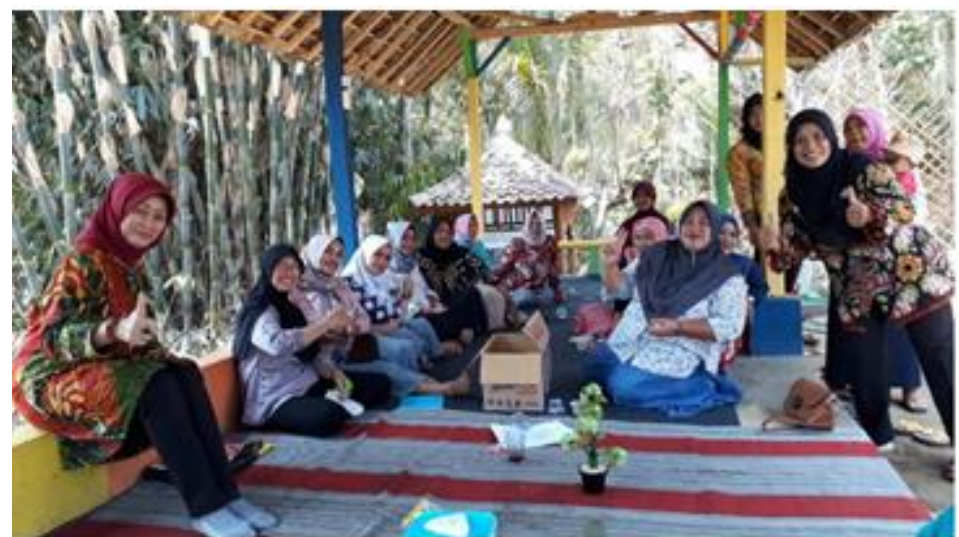

Gambar 1. Sosialisasi Pemanfaatan Rumah Sebagai Homestay

Sumber: Penulis, 2020
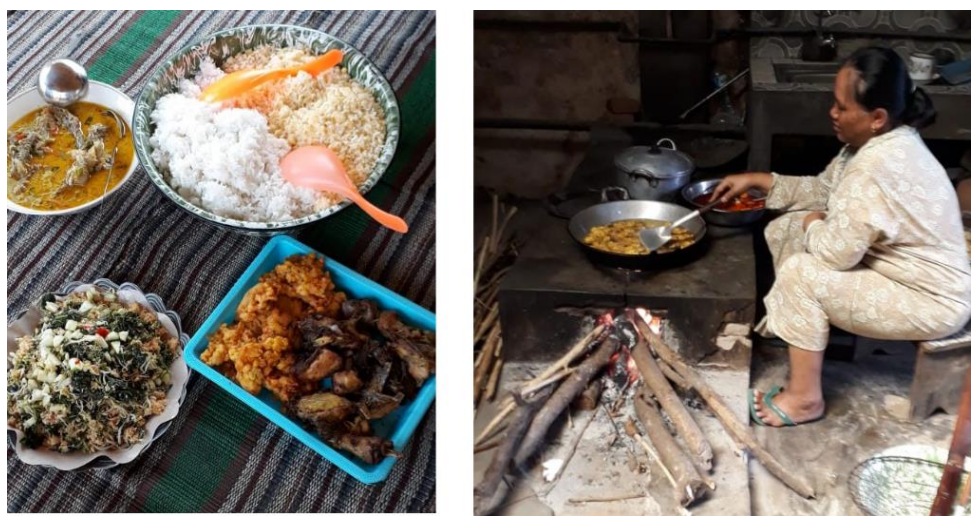

Gambar 2. Potensi Kuliner dari Ibu Rumah Tangga di Kampoeng Boenga Grangsil.

Sumber: Penulis, 2020

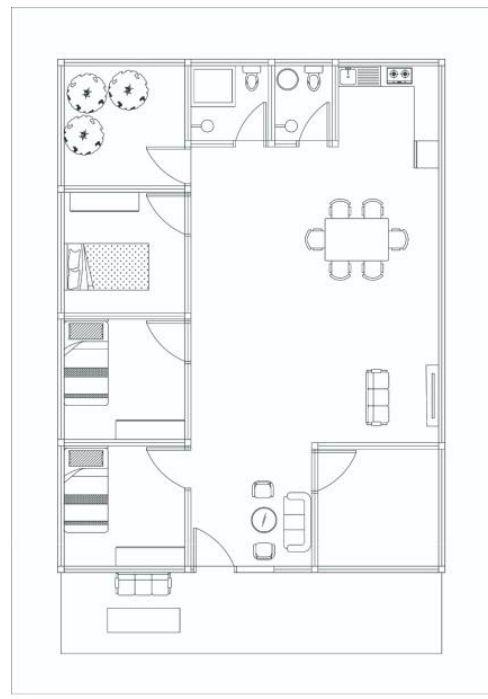

(a)

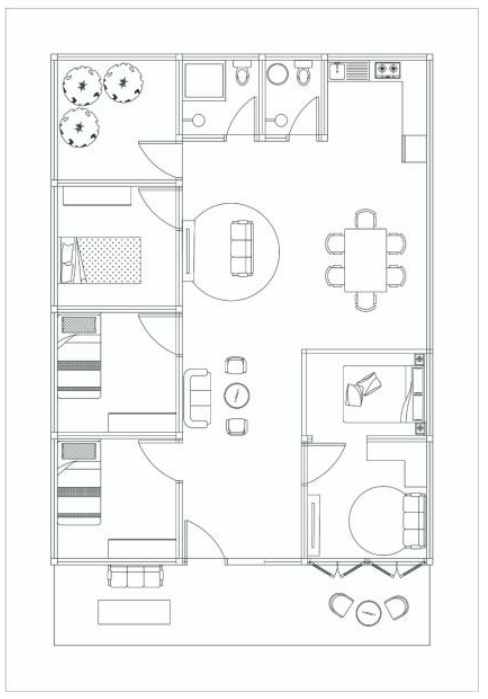

(b)

Gambar 3. Contoh Penataan Layout Salah Satu Rumah untuk Homestay (a) Denah Asal (b) Setelah Penataan Ulang Sumber : Penulis 2020 
Penataan ulang layout ruang diupayakan dengan biaya yang terjangkau, namun tetap memperhatikan estetika dan kebutuhan pemilik rumah maupun wisatawan yang tinggal. Dengan memperhatikan acuan Kementrian Pariwisata Republik Indonesia (2018) penataan kamar dilakukan dengan memperhatikan penghawaan yang cukup, dan sarana standar bilik inap yaitu : matras dan bantal, sprei, selimut, handuk, tempat sampah dan sumber listrik. Dilengkapi pula dengan cermin, petunjuk arah kiblat dan wifi.

\section{d. Pelatihan Guiding}

Setiap pemilik homestay diharapkan mampu menjadi guide atau pemandu wisata bagi para tamunya agar dapat mengeksplor kawasan wisata ini dengan baik. Ada 5 kompetensi yang selayaknya dimiliki oleh pemandu wisata, yaitu : 1) Bekerjasama dengan Kolega dan wisatawan. 2) Bekerja dalam Lingkungan Sosial yang bebeda, 3) Mengikuti Prosedur Kesehatan, Keselamatan dan Keamanan di Tempat Kerja. 4) Menangani Situasi Konflik Seminar Pariwisata \& Pembangunan Ekonomi. 5) Mengembangkan dan Memutakirkan Pengetahuan Pariwisata (Supriadi, 2015). Berdasarkan hal tersebut, maka ibu-ibu rumah tangga dan anggota Karang Taruna diberikan pendampingan berupa pelatihan guiding. Sasaran pelatihan ini selain bagaimana berkomunikasi yang baik dalam menjelaskan sarana wisata yang ada, juga memberikan edukasi protokol kesehatan sesuai standar bagi pemilik rumah, penyediaan sarananya, penghuni, dan bagaimana pemilik rumah mengkomunikasikannya pada tamu mereka. Protokol Kesehatan ini merujuk pada Kementrian pariwisata dan ekonomi Kreatif, (2020). Selain memahami Kawasan wisata dengan baik, diperlukan pemahaman tentang potensi utama pertanian bunga yaitu melalui penyiapan katalog bunga untuk mempermudah guide menjawab keinginan wisatawan yang ingin berbelanja bunga. Gambar 4 dapat memberikan gambaran tentang pokok-pokok yang perlu dipahami pemandu wisata dalam berkomunikasi sekaligus tetap menerapkan protokol kesehatan bagi diri sendiri, tempat wisata dan wisatawan.

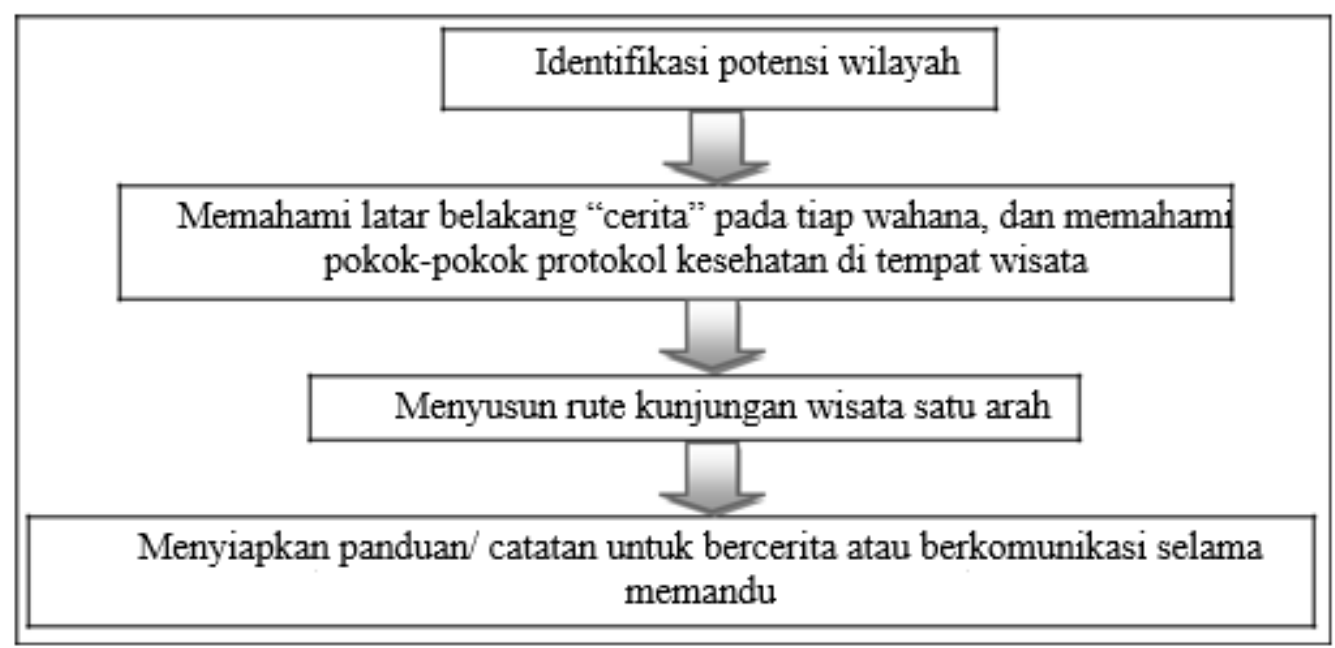

Gambar 4. Bagan guiding Desa Wisata pada Masa New Normal : Sumber : Penulis 2020

\section{e. Pelatihan Pemasaran dan Pengelolaan Keuangan}

Rusata (2015) telah melakukan kajian tentang potensi peningkatan perilaku konsumtif kelas menengah pada industri pariwisata saat ini. Kampoeng Boenga Grangsil menjadi salah satu destinasi wisata yang cukup menarik dari segi harga. Kesempatan untuk menangkap pasar wisatawan domestik yang terdiri dari kelas menengah sangat terbuka. Kondisi ini memungkinkan ibu rumah tangga di Kawasan Kampoeng Boenga Grangsil untuk menambah pendapatan melalui 
penyediaan penginapan dan kuliner. Potensi pendapatan yang ada pada masing-masing rumah tangga akan menjadi sia-sia, jika pengeloaannya tidak teratur. Maka Tim pengabdi memberikan cara-cara sederhana dalam mengelola keuangan homestay. Mulai dengan memberikan buku catatan kehadiran tamu, buku kas, membatu menghitung harga jual yang pantas, menyusun katalog kuliner, dan promo paket wisata. Pendampingan sangat disesuaikan dengan kemampuan warga. Catatan keuangan dibuat sesederhana mungkin sehingga mereka dengan mudah dapat melakukan sehari-hari. Formulir buku tamu dan catatan keuangan sederhana dapat dilihat pada Gambar 5.

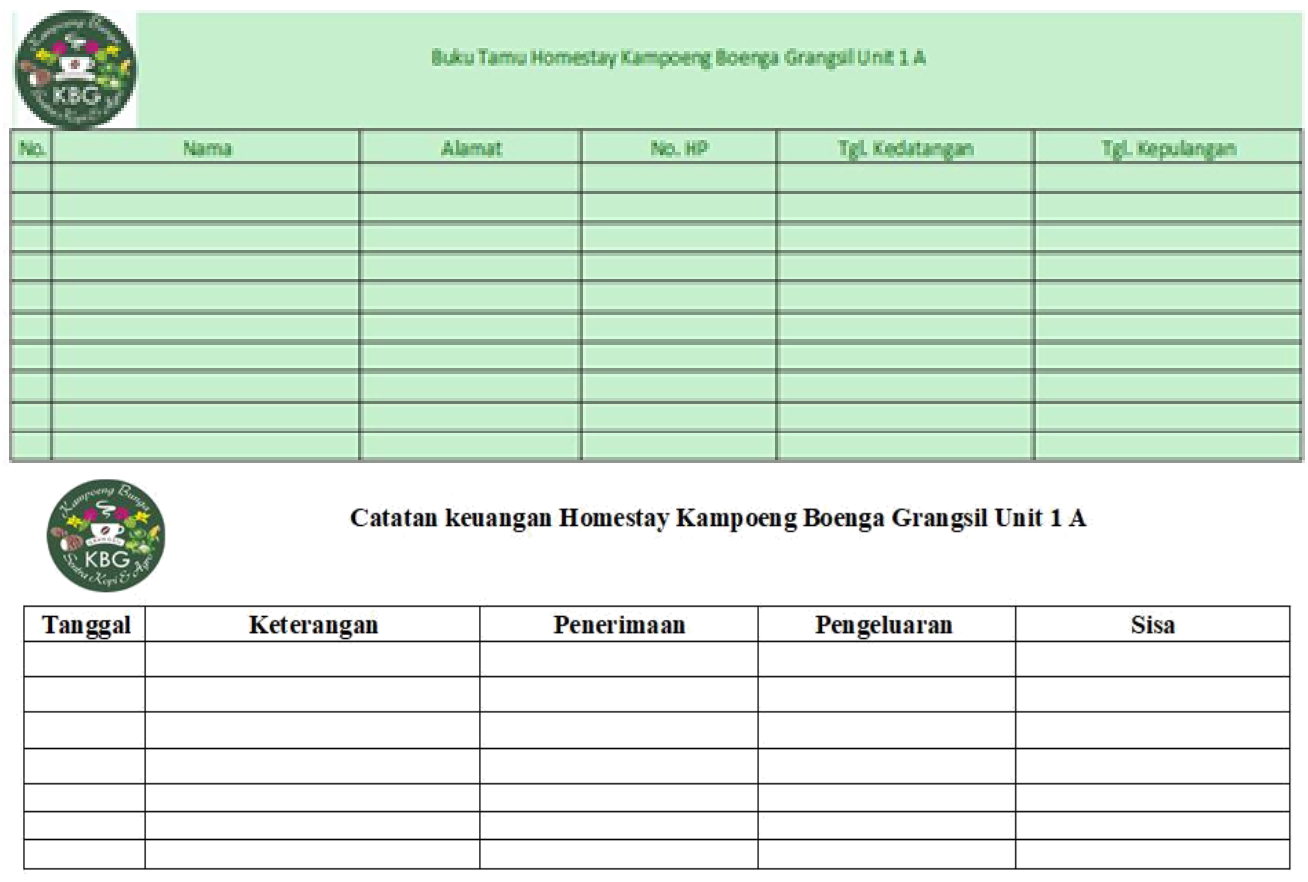

Gambar 5. Formulir Buku Tamu dan Catatan Keuangan Sederhana Sumber: Penulis, 2020

Promosi wisata didorong dengan memberdayakan potensi sosial media anggota Karang Taruna. Sebagaimana umumnya generasi muda pada era 2020, hampir semua anggota Karang Taruna memiliki akses instagram, facebook atau sosial media lain. Penggunaan media sosial yang tepat, mampu meningkatkan mempromosikan Desa Wisata mereka dan menarik minat wisata bagi para netizen (warga dunia maya) yang membaca dan mengikuti media (Hamzah et al., 2013). Pemasaran berbasis sosial media dan dukungan IT dalam Kawasan wisata menjadi sangat diperlukan (Handoko, 2014). Dalam rangka pemasaran yang lebih terarah, tim pendamping membantu membuat flyer promo paket wisata, dan memandu ibu-ibu anggota PKK Bunga Matahari untuk menyiapkan proposal kerjasama kegiatan live in, dengan sekolah-sekolah di Kota Malang untuk masa setelah kondisi kesehatan masyarakat telah kondusif. Kegiatan live-in ini pada masa sebelum Pandemi merupakan kegiatan softskill untuk membentuk karakter gotong royong dan kebersahajaan siswa yang berada di Kawasan kota Malang, untuk merasakan tinggal di pedesaaan. Diharapkan kegiatan tersebut dapat diagendakan lagi pada saat kondisi pandemik telah berlalu, meski dengan tetap memperhatikan protokol kesehatan. Potensi kuliner yang ada dikembangkan dengan membuat paket kuliner yang dapat dipromosikan, di Dusun Grangsil ini ada tiga potensi kuliner yang cukup layak dipromosikan, yaitu : kopi, keripik talas, serta menthok (sejenis itik manila) yang dimasak dengan bumbu lengkap, dan bercitarasa pedas. 


\section{KESIMPULAN DAN SARAN}

Pengabdian yang dilakukan oleh Tim ini berdurasi 1 tahun. Jangka waktu ini, relatif singkat untuk mencapai semua target luaran, terutama kendala yang terjadi di masa Pandemi COVID-19 ini mengurangi frekuensi kunjungan Desa dan pemantauannya. Maka, upaya lain adalah dengan memanfaatkan sarana komunikasi jarak jauh, agar tercapai semua target luaran pada waktu yang direncanakan. Dari apa yang telah dilakukan selama kurun waktu pengabdian masyarakat, Tim Pengabdi berharap dampak positif dari kegiatan ini adalah (1) Hasil Penataan yang lebih baik pada rumah yang dimanfaatkan sebagai homestay; (2) Peningkatan kemampuan dan kreatifitas warga dalam partisipasinya pada program Desa Wisata.; (3) Peningkatan peran ibu rumahtangga dalam menambah pendapatan keluarga; (4) Peningkatan ekonomi masyarakat pada umumnya. Pengabdian ini menjadi sebuah kolaborasi lintas ilmu dengan harapan bagi pengabdi dari bidang arsitektur dapat menerapkan dan mengembangkan konsep penataan ruang dan kawasan wisata. Bagi pengabdi dari bidang ilmu komunikasi dapat memberikan wawasan komunikasi guiding yang baik dan mudah dipahami warga, dan bagi tim pengabdi dengan latar belakang akuntansi mampu berbagi ilmu akuntansi terapan sederhana yang memudahkan warga dusun mengelola kegiatan homestay ini. Dari kegiatan PKM ini dihasilkan pula buku panduan wisata Kampoeng Boenga Grangsil, yang diharapkan memberi manfaat jangka panjang bagi Tim Pokdarwis Dusun Grangsil, dan prosiding pada kegiatan SENAPENMAS Univ. Tarumanegara 2020, serta artikel ilmiah guna menyebarluaskan konsep dan semangat pengabdian Desa di kalangan akademisi.

\section{Ucapan Terima Kasih (Acknowledgement)}

Pelaksanaan Pengabdian ini merupakan kewajiban Tim Pengabdi dalam mengamalkan Tri Darma Perguruan Tinggi. Kegiatan ini didanai oleh Universitas Merdeka Malang, sebagai bentuk hibah internal institusi sesuai salah satu misi Universitas Merdeka Malang yaitu menyelenggarakan kegiatan penelitian dan pengabdian kepada masyarakat serta publikasi ilmiah untuk mendorong peningkatan image dan reputasi lembaga serta terciptanya suasana akademik yang kondusif bagi terselenggaranya institusi pendidikan yang memiliki reputasi nasional dan internasional.

\section{REFERENSI}

Antara, M., \& Arida, N. S. (2015). Panduan Pengelolaan Desa Wisata Berbasis Potensi Lokal. Konsorium Riset Pariwisata Universitas Udayana, 23.

Astuti, M. (2014). Potensi Agrowisata Dalam Meningkatkan Pengembangan Pariwisata. Jurnal Destinasi Kepariwisataan, 1(17), 51-57.

Chusmeru. (2018). Desa Wisata, Sebuah Euphoria Pariwisata. Purwokerto.Com. https://purwokertokita.com/kolom/desa-wisata-sebuah-euphoria-pariwisata.php

Hadiwijono, S. S. (2012). Perencana Pariwisata Pedesaan berbasis Masyarakan (Sebuah Pendekatan Konsep). In Graha Ilmu (Vol. 1, Issue 1). https://doi.org/10.1017/CBO9781107415324.004

Hamzah, Y. I., Penelitian, P., Pengembangan, D., Kepariwisataan, K., Pariwisata, K., \& Kreatif, D. E. (2013). Potensi Media Sosial Sebagai Sarana Promosi Interaktif Bagi Pariwisata Indonesia. Jurnal Kepariwisataan Indonesia, 8(3), 1-9. http://www.kemenpar.go.id/userfiles/JKI Vol_8 No_3 2013 - Potensi Media Sosial Sebagai Sarana Promosi Interaktif Bagi Pariwisata Indonesia.pdf

Handoko, T. A. (2014). Perancangan Enterprise Architecture Layanan Informasi Kepariwisataan Dengan Pendekatan Service Oriented Architecture Studi Kasus : Kementerian Pariwisata Dan Ekonomi Kreatif. Jurnal Kepariwisataan Indonesia, 9(4), 413-427.

Kementrian pariwisata dan ekonomi Kreatif. (2020). Panduan Pelaksanaan Kelestarian Lingkungan di Daya Tarik Wisata Panduan Pelaksanaan Kelestarian Lingkungan di Daya Tarik Wisata. 2019. 
Kementrian Pariwisata Republik Indonesia. (2018). Panduan Pengembangan Homestay Desa Wisata untuk Masyarakat (3rd ed.). Kementrian Pariwisata Republik Indonesia.

Prajnawrdhi, T. A. (2016). Konsep tata kelola homestay di desa wisata pinge kabupaten tabanan. 337, 101-108.

Rusata, T. (2015). Kelas Menengah Baru Dan Tantangannya Bagi Industri Pariwisata Indonesia. Jurnal Kepariwisataan Indonesia, 10(1), 19-30.

Supriadi, B. (2015). Peningkatan Kemampuan Teknik Guiding Sebagai Kriteria Unjuk Kerja Pemandu Wisata Dalam Antisipasi Menuju Masyarakat Ekonomi ASEAN 2015. May 2014.

Tim Penggerak PKK Pusat. (2015). Rumusan Hasil Rakernas VIII PKK. 69. https://tppkkpusat.org/wp-content/uploads/2017/11/Buku-PKK-2015-R2.pdf

Tyas, N. W., \& Damayanti, M. (2018). Potensi Pengembangan Desa Kliwonan sebagai Desa Wisata Batik di Kabupaten Sragen. Journal of Regional and Rural Development Planning, 2(1), 74. https://doi.org/10.29244/jp2wd.2018.2.1.74-89

Wikantiyoso, R., Sukanti, D., Sulaksono, A. G., \& Widayati, S. (2019). Empowerment and strengthening of community resilience in developing ecotourism destination in Grangsil Hamlet, Malang Regency, Indonesia. Conference: 3rd Endinamosis 2019 International Conference on "Empowering Rural Areas in the Industry 4.0 Era," 11. 